https://journal-computing.org/index.php/journal-cisa/index

\title{
Analisis Kepuasan Pengguna Terhadap Penggunaan Aplikasi Transportasi Online Dengan Metode Unified Theory Of Acceptance And Use Of Technology
}

\author{
Geri Esmemed ${ }^{1}$, Gusmelia Testiana2 ${ }^{2}$, Fathiyah Nopriani ${ }^{3}$ \\ ${ }^{1}$ Sains dan Teknologi, Universitas Islam Raden Fatah, Palembang, Indonesia \\ 2,3Sistem Informasi, Universitas Islam Negeri Raden Fatah, Palembang, Idnonesia \\ Email: 1geriesmemed2@gmail.com, 2gusmeliatestiana_uin@radenfatah.ac.id ${ }^{3}$ \\ fathiyahnopriani_uinradenfatah.ac.id
}

\begin{abstract}
This study aims to determine the level of user satisfaction with the use of online transportation applications in the Raden Fatah State Islamic University Palembang using the unified theory of acceptance and use of technology (UTAUT) method. This study uses all the variables in the UTAUT methods, including moderation. The data in this study were collected using a questionnaire distributed to 298 respondents in the Raden Fatah State Islamic University Palembang. Data analysis was performed using descriptive analysis, simple regression analysis and moderated regression analysis. The results of this study indicate the level of user satisfaction with the use of online transportation applications in the Raden Fatah State Islamic University Palembang is $77.69 \%$. From this percentage, it can be concluded that the use of online transportation applications has been declared satisfied, especially within the Raden Fatah State Islamic University of Palembang.
\end{abstract}

Keywords: Online transportation application, UTAUT, User Satisfaction. 


\section{Journal of Computer and Information Systems Ampera}

Vol. 2, No. 2, May 2021 e-ISSN: 2775-2496

https://journal-computing.org/index.php/journal-cisa/index

\section{PENDAHULUAN}

Revolusi Industri yang pertama terjadi pada abad ke-18 ditandai dengan penemuan mesin uap yang digunakan untuk proses produksi barang, revolusi kedua terjadi di awal abad ke-20 revolusi industri ini ditandai dengan penemuan tenaga listrik, setelah revolusi industri kedua, setelah revolusi ini, abad industri pelan-pelan berakhir dan abad informasi dimulai.kemajuan teknologi komputer berkembang luar biasa pesat setelah perang dunia kedua selesai, komputer pun mulai menggantikan banyak manusia sebagai operator dan pengendali lini produksi.inilah revolusi industri yang saat ini sedang ramai diperbincangkan Industri 4.0 adalah tren di dunia industri yang menggabungkan teknologi otomatisasi dengan teknologi siber, tren ini telah mengubah banyak bidang kehidupan manusia, termasuk ekonomi, dunia kerja, bahkan gaya hidup, singkatnya revolusi industri 4.0 menanamkan teknologi cerdas yang dapat terhubung dengan berbagai bidang kehidupan manusia.

Keberadaan aplikasi di Indonesia yang kemudian menjadi trend yaitu transportasi berbasis aplikasi yang dilirik sebagai model e-business dikarenakan transportasi sendiri merupakan hal yang dasar untuk kehidupan manusia dalam

melakukan perpindahan dari suatu tempat ke tempat lain. Salah satu transportasi berbasis aplikasi e-bussiness yang ada di Indonesia yaitu Gojek. Kehadiran jasa transportasi berbasis aplikasi online yang menggunakan internet sangat berpengaruh bagi masyarakat dalam segala aktifitas secara cepat dan efisien. Salah satu bisnis yang sedang berkembang saat ini adalah bisnis jasa transportasi dengan sepeda motor atau yang dulu biasa disebut ojek.

Secara umum aplikasi ojek online sangatlah berguna bagi masyarakat di Indonesia pada era Globalisasi ini sehingga kepuasan pengguna dalam mendapatkan layanan dari aplikasi tersebut sangatlah harus di perhatikan. Menurut Zeithaml dan Bitner (2000:75) kepuasan adalah respon atau tanggapan konsumen mengenai pemenuhan kebutuhan. Kepuasan merupakan penilaian mengenai ciri atau keistimewaan produk atau jasa, atau produk itu sendiri, yang menyediakan tingkat kesenangan konsumen berkaitan dengan pemenuhan kebutuhan konsumsi konsumen. 
https://journal-computing.org/index.php/journal-cisa/index

Kepuasan konsumen merupakan faktor yang sangat penting bagi keberadaan, kelangsungan, dan perkembangan perusahaan. Saat ini banyak perusahaan yang semakin memahami arti penting dari kepuasan konsumen dan menjalankan strategi guna memberikan kepuasan bagi konsumennya, dengan demikian perlu dilakukan analisis terhadap sistem atau teknologi yang digunakan oleh konsumen perusahaan tersebut. Sebagaimana menurut Jimmy L. Goal (2008:73) Pengertian analisis sistem adalah sebagai penguraian dari suatu sistem informasi yang utuh kedalam bagianbagian komponennya dengan maksud untuk mengidentifikasikan dan mengevaluasi permasalahan-permasalahan, kesempatankesempatan, hambatan yang terjadi dan

kebutuhan yang diharapkan sehingga dapat diusulkan perbaikanperbaikannya.

Berdasarkan hal tersebut, maka peneliti ingin melakukan kegiatan analisis kepuasan pengguna terhadap penggunaan aplikasi transpotasi online untuk mengetahui besarnya tingkat kepuasan pengguna terhadap penggunaan aplikasi transportasi online

\section{METODE}

Metode yang digunakan dalam penelitian yaitu metode penelitian dan metode kepuasan pengguna. Adapan metode penelitian yang digunakan adalah metode kuantitatif dan untuk metode kepuasan pengguna yang digunakan adalah metode UTAUT

\subsection{Metode Penelitian}

Metode penelitian yang digunakan dalam penelitian ini adalah metode kuantitatif dimana hasil dari penelitian ini dituangkan dalam bentuk angka yang dihitung menggunakan SPSS. Alasan penelitian ini menggunakan metoe penelitian kuantitatif karena sifat data atau hasil penelitian bercorak kuantitatif, dimana penelitian ini menghasilkan data berupa angka yang didapat dari langkah-langkah yang ada pada metode UTAUT yang merupakan hasil pengetahuan atau pendapat pengguna setelah menyebarkan kuisioner di lapangan. 


\section{Journal of Computer and Information Systems Ampera}

Vol. 2, No. 2, May 2021 e-ISSN: 2775-2496

https://journal-computing.org/index.php/journal-cisa/index

\subsection{Metode Kepuasan Pengguna}

Berdasarkan Venkatesh et al, (2003) Model Unified Theory of Acceptance and Use of Technology (UTAUT) merupakan salah satu model yang dapat digunakan untuk menjelaskan penerimaan pengguna (user acceptance) dalam bidang sistem informasi karena UTAUT merupakan gabungan delapan model penerimaan teknologi terkemuka yaitu:

1. Teori tindakan beralasan (Theory of Reasoned Action / TRA)

2. Model penerimaan teknologi (Technology Acceptance Model / TAM)

3. Model motivasional (Motivational Model / MM)

4. Teori perilaku rencanaan (Theory of Planned Behavior / TPB)

5. Model gabungan TAM dan TPB (A Model Combining The Technology Acceptance Model and Tthe Theory of Planned Behavior / TAM +TPB)

6. Model Pemanfaatan PC (Model of PC Utilization / MPCU)

7. Teori difusi inovasi (Innovation Diffusion Theory / IDT)

8. Teori kognitif social (Social Cognitive Theory / SCT)

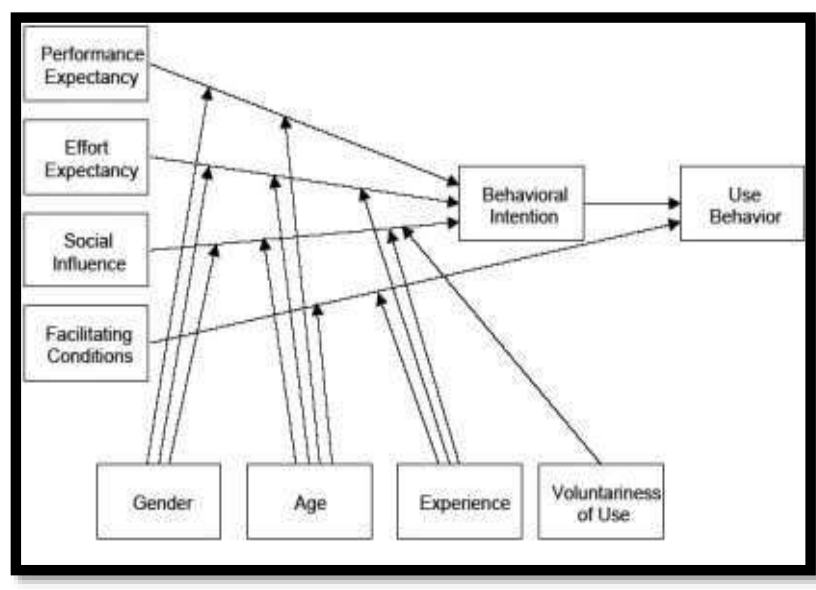

Sumber : Venkatesh et al (2003)

Gambar 2.1. Metode UTAUT

Berikut penjelasan deerminan UTAUT dari gambar diatas :

1. Ekspektasi Kinerja (performance expentancy) didefinisikan sebagai seberapa tinggi seseorang percaya bahwa menggunakan suatu sistem akan membantu dia mendapatkan keuntungan kinerja pekerjaannya.

2. Ekspektasi Usaha (effort expectancy), didefinisikan sebagai tingkat kemudahan yang dihubungkan dengan penggunaan suatu sistem. Kalau 
sistem mudah digunakan maka usaha yang dilakukan tidak akan terlalu tinggi dan sebaliknya jika suatu sistem sulit digunakan maka diperlukan usaha yang tinggi untuk menggunakannya.

3. Pengaruh Sosial (social influence), didefinisikan sebagai sejauh mana seorang individual mempersepsikan kepentingan yang dipercaya oleh orang lain yang akan mempengaruhinya menggunakan sistem yang baru.

4. Kondisi Fasilitas (facilitating condition) didefinisikan sebagai sejauh mana seseorang percaya bahwa infrastruktur organisasional dan teknikal tersedia untuk mendukung sistem.

Keempat determinan tersebut mempunyai peran penting dan memiliki pengaruh langsung pada niat untuk berperilaku (behavioral intention) dan perilaku untuk menggunakan suatu teknologi (use behavior). Kemudian keempat determinan tersebut dimoderasi oleh jenis kelamin (gender), umur (age), pengalaman (experience) dan kesukarelaan (voluntariness).

\subsection{Tahapan Penelitian}

Tahapan penelitian menggambarkan proses penelitian yang akan ditempuh sekaligus menggambarkan penelitian secara keseluruhan. Tahapan penelitian dapat dilihat pada Gambar 2.2 berikut

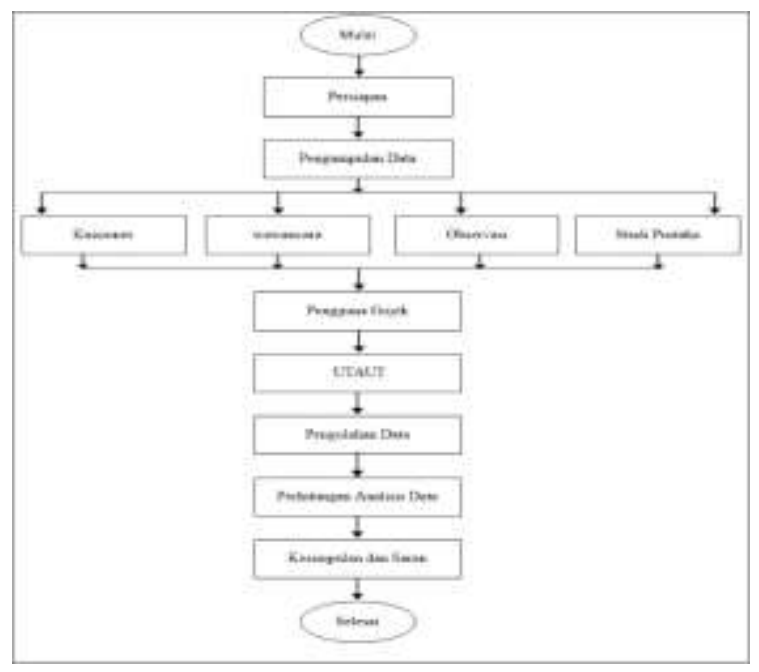

Gambar 2.2 Tahapan Penelitian 


\section{Journal of Computer and Information Systems Ampera}

Vol. 2, No. 2, May 2021 e-ISSN: 2775-2496

https://journal-computing.org/index.php/journal-cisa/index

\section{HASIL DAN PEMBAHASAN}

Penelitian ini menerapkan seluruh tahapan yang ada pada UTAUT dengan menggunakan tahapan-tahapan yang telah disediakan pada UTAUT. Berikut hasil dari langkah-langkah UTAUT:

1. Analisis dengan metode likert untuk mendapatkan range kategori.

Tabel 3.1 Range Variabel Ekspektasi Kinerja

\begin{tabular}{|c|c|c|c|c|c|}
\hline 0 & $20 \%$ & $40 \%$ & $60 \%$ & $\mathbf{7 8 , 6 9 \%}$ & $80 \% 100 \%$ \\
\hline & STS & TS & CS & S & SS \\
\hline
\end{tabular}

Tabel 3.2 Range Variabel Ekspektasi Usaha

\begin{tabular}{|r|c|c|c|c|cc|}
\hline 0 & $20 \%$ & $40 \%$ & $60 \%$ & $80 \%$ & $\mathbf{8 0 , 5 9 \%}$ & $100 \%$ \\
\hline & STS & TS & CS & S & \multicolumn{2}{|c|}{ SS } \\
\hline
\end{tabular}

Tabel 3.3 Range Variabel Pengaruh Sosial

\begin{tabular}{|l|l|l|l|ll|l|}
\hline 0 & $20 \%$ & $40 \%$ & $60 \%$ & $\mathbf{7 4 , 2 0 \%}$ & $\mathbf{8 0 \%}$ & $100 \%$ \\
\hline & STS & TS & CS & S & & SS \\
\hline
\end{tabular}

Tabel 3.4 Range Variabel Kondisi Fasilitas

\begin{tabular}{|c|c|c|c|c|cc|}
\hline 0 & $20 \%$ & $40 \%$ & $60 \%$ & $80 \%$ & $\mathbf{8 4 , 8 9 \%}$ & $100 \%$ \\
\hline & STS & TS & CS & S & SS & \\
\hline
\end{tabular}

Tabel 3.5 Range Variabel Niat Untuk Berperilaku

\begin{tabular}{|c|c|c|c|c|c|}
\hline 0 & $20 \%$ & $40 \%$ & $60 \%$ & $74 \% \quad 80 \%$ & $100 \%$ \\
\hline & STS & TS & $\mathrm{CS}$ & $\mathrm{S}$ & SS \\
\hline
\end{tabular}

83 | Analisis Kepuasan Pengguna Terhadap Penggunaan Aplikasi... 


\section{Journal of Computer and Information Systems Ampera}

Vol. 2, No. 2, May 2021 e-ISSN: 2775-2496

https://journal-computing.org/index.php/journal-cisa/index

Tabel 3.6 Range Variabel Perilaku Menggunakan

\begin{tabular}{|l|l|l|l|ll|l|}
\hline 0 & $20 \%$ & $40 \%$ & $60 \%$ & $\mathbf{7 3 , 7 5 \%}$ & $\mathbf{8 0 \%}$ & $100 \%$ \\
\hline & STS & TS & CS & S & & SS \\
\hline
\end{tabular}

Tabel 3.7 Range Variabel Keseluruhan

\begin{tabular}{|l|l|l|l|ll|l|}
\hline 0 & $20 \%$ & $40 \%$ & $60 \%$ & $\mathbf{7 7 , 6 9 \%}$ & $\mathbf{8 0 \%}$ & $100 \%$ \\
\hline & STS & TS & CS & S & & SS \\
\hline
\end{tabular}

Dari range kategori tersebut dapat dilihat bahwa dari hasil distribusi persentase jawaban berdasarkan variabel keseluruhan adalah sebesar 77,69\% adalah termasuk kedalam kategori setuju. Hal ini dapat diartikan besarnya kepuasan pengguna terhadap penggunaan aplikasi transportasi online dilingkungan UIN Raden Fatah Palembang adalah sebesar 77,69\%. Dari hasil tersebut dapat dilihat bahwa yang mendominasi terhadap kepuasan pelanggan terdapat pada variabel kondisi fasilitas sebesar $84,89 \%$, sedangkan yang paling sedikit mempengaruhi terhadap kepuasan pelanggan terdapat pada varibel perilaku menggunakan sebesar 73,75\%, akan tetapi dapat disimpulkan bahwa variabel ekspektasi kinerja, ekspektasi usaha, pengaruh sosial, kondisi pemfasilitasi, niat untuk berperilaku, perilaku menggunakan dapat diterima oleh responden.

2. Analisis Regresi Linier Sederhana

Tabel 3.8 Hasil Uji T1

\begin{tabular}{|c|c|c|c|c|c|c|}
\hline \multicolumn{7}{|c|}{ Coefficients $^{\mathbf{a}}$} \\
\hline & & \multicolumn{2}{|c|}{ Unstandardized Coefficients } & \multirow{2}{*}{$\begin{array}{c}\text { Standardized } \\
\text { Coefficients } \\
\text { Beta } \\
\end{array}$} & \multirow[b]{2}{*}{$\mathrm{T}$} & \multirow[b]{2}{*}{ Sig. } \\
\hline \multicolumn{2}{|c|}{ Model } & $\mathrm{B}$ & Std. Error & & & \\
\hline \multirow[t]{2}{*}{1} & (Constant) & 10.103 & 1.463 & & 6.907 & .000 \\
\hline & $\mathrm{X} 1$ & .427 & .074 & .317 & 5.756 & .000 \\
\hline
\end{tabular}

(Sumber: diolah dengan SPSS versi 25) 


\section{Journal of Computer and Information Systems Ampera}

Vol. 2, No. 2, May 2021 e-ISSN: 2775-2496

https://journal-computing.org/index.php/journal-cisa/index

Dari tabel Hasil Uji T1 untuk variabel X1 diperoleh nilai thitung > ttabel $(5,756>1,960$ dan signifikansi $<0,05(0,000<0,05)$ maka Ho ditolak dan Ha diterima.

Tabel 3.9 Hasil Uji T2

\begin{tabular}{|c|c|c|c|c|c|c|}
\hline \multicolumn{7}{|c|}{ Coefficients $^{\mathrm{a}}$} \\
\hline & & \multicolumn{2}{|c|}{ Unstandardized Coefficients } & \multirow{2}{*}{$\begin{array}{c}\text { Standardized } \\
\text { Coefficients } \\
\text { Beta } \\
\end{array}$} & \multirow[b]{2}{*}{$\mathrm{T}$} & \multirow[b]{2}{*}{ Sig. } \\
\hline \multicolumn{2}{|c|}{ Model } & B & Std. Error & & & \\
\hline \multirow[t]{2}{*}{1} & (Constant) & 5.735 & 1.465 & & 3.915 & .000 \\
\hline & $\mathrm{X} 2$ & .634 & .073 & .453 & 8.734 & .000 \\
\hline
\end{tabular}

(Sumber: diolah dengan SPSS versi 25)

Dari tabel Hasil Uji T2 untuk variabel X2 diperoleh nilai thitung > ttabel $(8,734>1,960)$

dan signifikansi $<0,05(0,000<0,05)$ maka Ho ditolak dan Ha diterima

Tabel 3.10 Hasil Uji T3

\begin{tabular}{|c|c|c|c|c|c|c|}
\hline \multicolumn{7}{|c|}{ Coefficients $^{a}$} \\
\hline & & \multicolumn{2}{|c|}{ Unstandardized Coefficients } & \multirow{2}{*}{$\begin{array}{c}\text { Standardized } \\
\text { Coefficients } \\
\text { Beta } \\
\end{array}$} & \multirow[b]{2}{*}{$\mathrm{T}$} & \multirow[b]{2}{*}{ Sig. } \\
\hline \multicolumn{2}{|c|}{ Model } & $\mathrm{B}$ & Std. Error & & & \\
\hline \multirow[t]{2}{*}{1} & (Constant) & 7.315 & .916 & & 7.985 & .000 \\
\hline & X3 & .603 & .049 & .581 & 12.273 & .000 \\
\hline
\end{tabular}

(Sumber: diolah dengan SPSS versi 25)

Dari tabel Hasil Uji T3 untuk variabel X3 diperoleh nilai thitung $>$ ttabel $(12.273>1,960)$ dan signifikansi $<0,05(0,000<0,05)$ maka Ho ditolak dan Ha diterima. 


\section{Journal of Computer and Information Systems Ampera}

Vol. 2, No. 2, May 2021 e-ISSN: 2775-2496

https://journal-computing.org/index.php/journal-cisa/index

Tabel 3.11 Hasil Uji T4

\begin{tabular}{|c|c|c|c|c|c|c|}
\hline \multicolumn{7}{|c|}{ Coefficients $^{\mathbf{a}}$} \\
\hline & & \multicolumn{2}{|c|}{ Unstandardized Coefficients } & \multirow{3}{*}{$\begin{array}{c}\text { Standardized } \\
\text { Coefficients } \\
\text { Beta }\end{array}$} & \multirow{3}{*}{$\begin{array}{l}\mathrm{T} \\
9.624 \\
\end{array}$} & \multirow{3}{*}{$\begin{array}{l}\text { Sig. } \\
\quad .000\end{array}$} \\
\hline \multicolumn{2}{|c|}{ Model } & B & Std. Error & & & \\
\hline \multirow[t]{2}{*}{1} & (Constant) & 15.080 & 1.567 & & & \\
\hline & X4 & .158 & .074 & .124 & 2.150 & .032 \\
\hline
\end{tabular}

a. Dependent Variable: Y2

(Sumber: diolah dengan SPSS versi 25)

Dari tabel Uji T4 untuk variabel X4 diperoleh nilai thitung $>$ ttabel $(2,150$ $>1,960)$ dan signifikansi $<0,05(0,032<0,05)$ maka Ho ditolak dan Ha diterima.

Tabel 3.12 Hasil Uji T5

\begin{tabular}{|c|c|c|c|c|c|c|}
\hline \multicolumn{7}{|c|}{ Coefficients $^{a}$} \\
\hline \multirow{2}{*}{\multicolumn{2}{|c|}{ Model }} & \multicolumn{2}{|c|}{ Unstandardized Coefficients } & \multirow{3}{*}{$\begin{array}{c}\text { Standardized } \\
\text { Coefficients } \\
\text { Beta } \\
\end{array}$} & \multirow{3}{*}{$\begin{array}{l}\mathrm{T} \\
10.999\end{array}$} & \multirow{3}{*}{$\begin{array}{l}\text { Sig. } \\
.000\end{array}$} \\
\hline & & $\mathrm{B}$ & Std. Error & & & \\
\hline \multirow[t]{2}{*}{1} & (Constant) & 11.210 & 1.019 & & & \\
\hline & Y1 & .391 & .055 & .383 & 7.134 & .000 \\
\hline
\end{tabular}

(Sumber: diolah dengan SPSS versi 25)

Dari tabel Hasil Uji T5 untuk variabel Y1 diperoleh nilai thitung $>$ ttabel $(7,134>1,960)$ dan signifikansi $<0,05(0,000<0,05)$ maka Ho ditolak dan Ha diterima. 


\section{Journal of Computer and Information Systems Ampera}

Vol. 2, No. 2, May 2021 e-ISSN: 2775-2496

https://journal-computing.org/index.php/journal-cisa/index

3. Analisis Regresi Moderisasi

Tabel 3.13 Anova ekspektasi kinerja moderasi jenis kelamin

\begin{tabular}{|l|l|r|r|r|r|r|}
\hline \multicolumn{7}{|c|}{ ANOVA $^{\text {Madel }}$} \\
\hline \multirow{3}{*}{1} & Sum of Squares & df & Mean Square & F & Sig. \\
\cline { 2 - 7 } & Regression & 118.601 & 3 & 39.534 & 11.352 & $.000^{\mathrm{b}}$ \\
\cline { 2 - 7 } & Residual & 1023.899 & 294 & 3.483 & & \\
\cline { 2 - 7 } & Total & 1142.500 & 297 & & & \\
\hline
\end{tabular}

a. Dependent Variable: NBY1

b. Predictors: (Constant), XZ, EKX1, GenderZ1

(Sumber: diolah dengan SPSS versi 25)

Dari tabel 3.13 diperoleh nilai Fhitung $>$ Ftabel $(11,352>2,65)$ dan signifikansi $<0,05(0,000<0,05)$ maka Ho ditolak dan Ha diterima.

Tabel 3.14 Anova ekspektasi kinerja moderasi umur

\begin{tabular}{|c|c|c|c|c|c|c|}
\hline \multicolumn{7}{|c|}{ ANOVA $^{a}$} \\
\hline \multicolumn{2}{|c|}{ Model } & Sum of Squares & df & Mean Square & $\mathrm{F}$ & Sig. \\
\hline \multirow[t]{3}{*}{1} & Regression & 136.202 & 3 & 45.401 & 13.264 & $.000^{\mathrm{b}}$ \\
\hline & Residual & 1006.298 & 294 & 3.423 & & \\
\hline & Total & 1142.500 & 297 & & & \\
\hline \multicolumn{7}{|c|}{ a. Dependent Variable: NBY1 } \\
\hline & : (Constan & 2, EKX1, Kel.Um & & & & \\
\hline
\end{tabular}

(Sumber: diolah dengan SPSS versi 25)

Dari tabel 3.14 diperoleh nilai Fhitung $>$ Ftabel $(12,264>2,65)$ dan signifikansi $<0,05(0,000<0,05)$ maka Ho ditolak dan Ha diterima. 


\section{Journal of Computer and Information Systems Ampera}

Vol. 2, No. 2, May 2021 e-ISSN: 2775-2496

https://journal-computing.org/index.php/journal-cisa/index

Tabel 3.15 Anova ekspektasi usaha moderasi jenis kelamin

\begin{tabular}{|l|l|r|r|r|r|r|}
\hline \multicolumn{7}{|c|}{ ANOVA $^{\text {Model }}$} \\
\hline \multirow{3}{*}{1} & Sum of Squares & \multicolumn{1}{c|}{ df } & Mean Square & \multicolumn{1}{c|}{ F } & Sig. \\
\cline { 2 - 7 } & Regression & 242.790 & 3 & 80.930 & 26.446 & $.000^{\mathrm{b}}$ \\
\cline { 2 - 7 } & Residual & 899.710 & 294 & 3.060 & & \\
\cline { 2 - 7 } & Total & 1142.500 & 297 & & & \\
\hline
\end{tabular}

a. Dependent Variable: NBY1

b. Predictors: (Constant), XZ, EUX2, GenderZ1

(Sumber: diolah dengan SPSS versi 25)

Dari tabel 3.15 diperoleh nilai Fhitung $>$ Ftabel $(26,446>2,65)$ dan signifikansi $<0,05(0,000<0,05)$ maka Ho ditolak dan Ha diterima.

Tabel 3.16 Anova ekspektasi usaha moderasi umur

\begin{tabular}{|c|c|c|c|c|c|c|}
\hline \multicolumn{7}{|c|}{ ANOVA $^{a}$} \\
\hline \multicolumn{2}{|c|}{ Model } & Sum of Squares & $\mathrm{df}$ & Mean Square & $\mathrm{F}$ & Sig. \\
\hline \multirow[t]{3}{*}{1} & Regression & 235.082 & 3 & 78.361 & 25.389 & $.000^{\mathrm{b}}$ \\
\hline & Residual & 907.418 & 294 & 3.086 & & \\
\hline & Total & 1142.500 & 297 & & & \\
\hline \multicolumn{7}{|c|}{ a. Dependent Variable: NBY1 } \\
\hline
\end{tabular}

(Sumber: diolah dengan SPSS versi 25)

Dari tabel 3.16 diperoleh nilai Fhitung $>$ Ftabel $(25,389>2,65)$ dan signifikansi $<0,05(0,000<0,05)$ maka Ho ditolak dan Ha diterima.

Tabel 3.17 Anova ekpektansi usaha moderasi pengalaman

\begin{tabular}{|c|c|c|c|c|c|c|}
\hline \multicolumn{7}{|c|}{ ANOVA $^{a}$} \\
\hline \multicolumn{2}{|c|}{ Model } & Sum of Squares & df & Mean Square & $\mathrm{F}$ & Sig. \\
\hline \multirow[t]{3}{*}{1} & Regression & 239.004 & 3 & 79.668 & 25.924 & $.000^{\mathrm{b}}$ \\
\hline & Residual & 903.496 & 294 & 3.073 & & \\
\hline & Total & 1142.500 & 297 & & & \\
\hline \multicolumn{7}{|c|}{ a. Dependent Variable: NBY1 } \\
\hline
\end{tabular}




\section{Journal of Computer and Information Systems Ampera}

Vol. 2, No. 2, May 2021 e-ISSN: 2775-2496

https://journal-computing.org/index.php/journal-cisa/index

Dari tabel 3.17 diperoleh nilai Fhitung $>$ Ftabel $(25,924>2,65)$ dan signifikansi $<0,05(0,000<0,05)$ maka Ho ditolak dan Ha diterima.

Tabel 3.18 Anova Pengaruh Sosial Moderasi Jenis Kelamin

\begin{tabular}{|c|c|c|c|c|c|c|}
\hline \multicolumn{7}{|c|}{ ANOVA $^{\mathbf{a}}$} \\
\hline \multicolumn{2}{|c|}{ Model } & Sum of Squares & $\mathrm{df}$ & Mean Square & $\mathrm{F}$ & Sig. \\
\hline \multirow[t]{3}{*}{1} & Regression & 389.602 & 3 & 129.867 & 50.712 & $.000^{\mathrm{b}}$ \\
\hline & Residual & 752.898 & 294 & 2.561 & & \\
\hline & Total & 1142.500 & 297 & & & \\
\hline \multicolumn{7}{|c|}{ a. Dependent Variable: NBY1 } \\
\hline
\end{tabular}

(Sumber: diolah dengan SPSS versi 25)

Dari tabel 3.18 diperoleh nilai Fhitung $>$ Ftabel $(60,304>2,65)$ dan signifikansi $<0,05(0,000<0,05)$ maka Ho ditolak dan Ha diterima.

Tabel 3.19 Anova Pengaruh Sosial Moderasi Umur

\begin{tabular}{|c|c|c|c|c|c|c|}
\hline \multicolumn{7}{|c|}{ ANOVA $^{a}$} \\
\hline \multicolumn{2}{|c|}{ Model } & Sum of Squares & df & Mean Square & $\mathrm{F}$ & Sig. \\
\hline \multirow[t]{3}{*}{1} & Regression & 388.801 & 3 & 129.600 & 50.554 & $.000^{\mathrm{b}}$ \\
\hline & Residual & 753.699 & 294 & 2.564 & & \\
\hline & Total & 1142.500 & 297 & & & \\
\hline \multicolumn{7}{|c|}{ a. Dependent Variable: NBY1 } \\
\hline
\end{tabular}

(Sumber: diolah dengan SPSS versi 25)

Dari tabel 3.19 diperoleh nilai Fhitung $>$ Ftabel $(58,438>2,65)$ dan signifikansi $<0,05(0,000<0,05)$ maka Ho ditolak dan Ha diterima. 


\section{Journal of Computer and Information Systems Ampera}

Vol. 2, No. 2, May 2021 e-ISSN: 2775-2496

https://journal-computing.org/index.php/journal-cisa/index

Tabel 3.20 Anova Pengaruh Sosial Moderasi Pengalaman

\begin{tabular}{|c|c|c|c|c|c|c|}
\hline \multicolumn{7}{|c|}{ ANOVA $^{a}$} \\
\hline \multicolumn{2}{|c|}{ Model } & Sum of Squares & Df & Mean Square & $\mathrm{F}$ & Sig. \\
\hline \multirow[t]{3}{*}{1} & Regression & 391.842 & 3 & 130.614 & 51.156 & $.000^{\mathrm{b}}$ \\
\hline & Residual & 750.658 & 294 & 2.553 & & \\
\hline & Total & 1142.500 & 297 & & & \\
\hline \multicolumn{7}{|c|}{ a. Dependent Variable: NBY1 } \\
\hline
\end{tabular}

(Sumber: diolah dengan SPSS versi 25)

Dari tabel 3.20 diperoleh nilai Fhitung $>$ Ftabel $(51,156>2,65)$ dan signifikansi $<0,05(0,000<0,05)$ maka Ho ditolak dan Ha diterima.

Tabel 3.21 Anova Pengaruh Sosial Moderasi Kesukarelaan

\begin{tabular}{|c|c|c|c|c|c|c|}
\hline \multicolumn{7}{|c|}{$\mathrm{ANOVA}^{\mathbf{a}}$} \\
\hline \multicolumn{2}{|c|}{ Model } & Sum of Squares & df & Mean Square & $\mathrm{F}$ & Sig. \\
\hline \multirow[t]{3}{*}{1} & Regression & 391.570 & 3 & 130.523 & 51.102 & $.000^{\mathrm{b}}$ \\
\hline & Residual & 750.930 & 294 & 2.554 & & \\
\hline & Total & 1142.500 & 297 & & & \\
\hline \multicolumn{7}{|c|}{ a. Dependent Variable: NBY1 } \\
\hline & : (Const: & 4, PSX3, Sukare & & & & \\
\hline
\end{tabular}

(Sumber: diolah dengan SPSS versi 25)

Dari tabel 3.21 diperoleh nilai Fhitung $>$ Ftabel $(51,102>2,65)$ dan signifikansi $<0,05(0,000<0,05)$ maka Ho ditolak dan Ha diterima.

Tabel 3.22 Anova Kondisi Pemfasilitasi Moderasi Umur

\begin{tabular}{|l|l|r|r|r|r|r|}
\hline \multicolumn{7}{|l|}{ ANOVA $^{\text {Model }}$} \\
\hline \multirow{3}{*}{1} & Sum of Squares & df & Mean Square & F & Sig. \\
\cline { 2 - 7 } & Regression & 61.453 & 3 & 20.484 & 5.339 & $.001^{\mathrm{b}}$ \\
\cline { 2 - 7 } & Residual & 1127.960 & 294 & 3.837 & & \\
\cline { 2 - 7 } & Total & 1189.413 & 297 & & & \\
\hline a. Dependent Variable: PMY2 \\
b. Predictors: (Constant), X4Z2, KFX4, Kel.Umur \\
\hline
\end{tabular}




\section{Journal of Computer and Information Systems Ampera}

Vol. 2, No. 2, May 2021 e-ISSN: 2775-2496

https://journal-computing.org/index.php/journal-cisa/index

Dari tabel 3.22 diperoleh nilai Fhitung $>$ Ftabel $(5,339>2,65)$ dan signifikansi < 0,05 $(0,001<0,05)$ maka Ho ditolak dan Ha diterima.

Tabel 3.23 Anova Kondisi Pemfasilitasi Moderasi Pengalaman

\begin{tabular}{|c|c|c|c|c|c|c|}
\hline \multicolumn{7}{|c|}{ ANOVA $^{a}$} \\
\hline \multicolumn{2}{|c|}{ Model } & Sum of Squares & df & Mean Square & $\mathrm{F}$ & Sig. \\
\hline \multirow[t]{3}{*}{1} & Regression & 25.120 & 3 & 8.373 & 3.118 & $.046^{\mathrm{b}}$ \\
\hline & Residual & 1164.293 & 294 & 3.960 & & \\
\hline & Total & 1189.413 & 297 & & & \\
\hline \multicolumn{7}{|c|}{ a. Dependent Variable: PMY2 } \\
\hline
\end{tabular}

(Sumber: diolah dengan SPSS versi 25)

Dari tabel 4.67 diperoleh nilai Fhitung $>$ Ftabel $(3,118>2,65)$ dan signifikansi $<0,05(0,046<0,05)$ maka Ho ditolak dan Ha diterima.

\section{KESIMPULAN}

Penelitian ini menggunakan metode UTAUT (unified theory of acceptance and use of technology) untuk mengetahui kepuasan pengguna terhadap penggunaan aplikasi transportasi online dilingkuan UIN Raden Fatah Palembang. Berdasarkan pembahasan Maka didapat kesimpulan sebagai berikut :

1. Berdasarkan analisis pada motode UTAUT dan data kuesioner dari 298 responden maka dapat diketahui presentase tingkat kepuasan pengguna terhadap penggunaan aplikasi transportasi online berdasarkan variabel-variabel yang ada pada metode UTAUT ialah, variabel ekspektasi kinerja sebesar 78,69\%, variabel ekspektasi usaha sebesar $80,59 \%$, vairabel pengaruh sosial sebesar $74,20 \%$, variabel kondisi fasilitas sebesar $84,89 \%$, variabel niat untuk berperilaku sebesar 74\%, variabel perilaku menggunakan sebesar 73,75\%, dapat disimpulkan untuk variabel keseluruhannya dikatakan puas dengan persentase sebesar 77,69\%. Hal ini menunjukkan bahwa aplikasi transportasi online khususnya dilingkungan UIN Raden Fatah Palembang sudah puas dan digunakan oleh responden. Tingkat kepuasan pengguna terhadap penggunaan aplikasi transportasi online juga dapat dilihat dari hasil perhitungan regresi yang dapat disimpulkan bahwa variabel ekspektasi kinerja, ekspektasi usaha, 
pengaruh sosial, jenis kelamin, umur, pengalaman dan kesukarelaan berpengaruh terhadap niat untuk berperilaku sedangkan kondisi pemfasilitasi berpengaruh terhadap perilaku menggunakan, serta niat untuk berperilaku mempengaruhi perilaku menggunakan aplikasi transportasi online.

2. Adapun faktor-faktor yang berpengaruh besar terhadap kepuasan pengguna terhadap penggunaan aplikasi transportasi online dilingkungan UIN Raden Fatah Palembang adalah kondisi fasilitas dan ekspektasi usaha. Sedangkan ekspektasi kinerja, pengaruh sosial berpengaruh kecil terhadap kepuasan pengguna dalam menggunakan aplikasi transportasi online dilingkungan UIN Raden Fatah Palembang.

3. Penelitian ini juga menunjukkan bahwa variabel moderasi yaitu jenis kelamin, umur, pengalaman dan kesukarelaan memperkuat semua hubungan variabel independen terhadap dependen. Variabel moderasi yang berpengaruh besar terhadap kepuasan pengguna dalam menggunakan aplikasi transportasi online adalah variabel pengaruh sosial dimoderasi pengalaman dan variabel pengaruh sosial dimoderasi kesukarelaan.

\section{REFERENCES}

[1] Abrar Hiswara, Sri Rejeki, Prio Kustanto, 2015. Analisis Aplikasi Mobile Dengan Menggunakan Metode UTAUT ( Unifiead Theory Of Acceptance And Use Of Technology ). Jurnal Teknologi Informasi Vol, 11, No. 02, 2017.

[2] Albert Yohanes, Devi Yuriska Bernanda, Johanes Fernandes Andry, James Surya Seputro, 2019. Analisis Sistem KRS Online Terhadap Kepuasan Mahasiswa Universitas XYZ Menggunakan Metode UTAUT. Jurnal TEKNOINFO, Vol, 13, No. 2, 2019, 124-130, ISSN:2615-224X

[3] Deni Kurniadi, Sintia Prasiska, Muhammad Anwar, 2018. Analisis Perilaku Penggunaan Aplikasi Ujian Sekolah Berbasis Komputer Menggunakan Model UTAUT (Unified Theory Of Acceptance And Use Of Technology) di Smk Negeri 1 Batipuh.

[4] Destiningrum, Diah. Dkk. 2018. Analisis Faktor Penerimaan Penggunaan E-Learning SMA Negeri Blitar Menggunakan Model Unified Theory Of Acceptance And Use Of Technology (UTAUT). 


\section{Journal of Computer and Information Systems Ampera}

Vol. 2, No. 2, May 2021 e-ISSN: 2775-2496

https://journal-computing.org/index.php/journal-cisa/index

Jurnal Pengembangan Teknologi Informasi dan Ilmu Komputer. Vol. 2, No.2.

[5] Ery Hartati, 2017. Analisis Sistem Penerapan E-Learning Dengan Menggunakan Metode UTAUT (Unified Theory Of Acceptance And Use Of Technology). Jurnal Ilmiah Informatika Global Volume 8 No.1 Juli 2017.

[6] Hardianti Safitri, 2018. Analisis Penerimaan dan Penggunaan Sistem E-Learning Pada UIN Raden Fatah Palembang Menggunakan Pendekatan UTAUT.

[7] Haryanto. 2017. Kajian Implementasi Pembelajaran Berbasis ELearning Dengan Pendekatan Unified Theory Of Acceptance And Use Of Technology (UTAUT) (Study Kasus pada SMP Al-Amanah, Kota Tanggerang Selatan). Jakarta: Jurnal Khatulistiwa Informatika, Vol. V, No.1.

[8] Hutami, Rr.Rieka F. Dan Dhea Ratna Camilia. 2016. Analisis Kepuasan Pada Pengguna Sistem Tcs Menggunakan Metode End User Computing Satisfaction (Studi Kasus: Pt. Tlk, Bandung), Bandung: Universitas Telkom. Vol.16 No.1, Jurnal Manajemen Indonesia:15-24.

[9] Kristoforus Jawa Bendi, R. dan Sri Andayani. 2013. Analisis Perilaku Penggunaan Sistem InformasiMenggunakan Model UTAUT. Palembang: Seminar Nasional Teknologi Informasi \& Komunikasi Terapan 2013 (Semantik 2013). ISBN: 979-26-0266-6.

[10] Luzi Dwi Oktaviana, Zanur Rifa'I, Kurnia Utami, 2017. Analisis Penerapan Sistem KRS Online Terhadap Kepuasan Mahasiswa STMIK Amikom Purwokerto Menggunakan Metode UTAUT.

[11] Megawaty, 2017. Implementasi UTAUT Dalam Menganalisis Pengaruh Penggunaan Aplikasi VMEET Terhadap Tingkat Kepuasan Belajar di Universitas Bina Darma Palembang. Jurnal Prosiding Seminar Nasional Pendidikan Teknik Informatika (SENEPATI) Ke-8 Bali, 09 September 2017.

[12] Siti Rahma, Nurmaini Dalimunthe, 2016. Analisis Perilaku Pengguna E-Learning Schoology Menggunakan Model UTAUT. Jurnal Ilmiah Rekayasa dan Manajemen Sistem Informasi, Vol, 2, No. 2, 2017. 